\title{
Earthquake-induced landslide scenarios for seismic microzonation: application to the Accumoli area (Rieti, Italy)
}

\author{
S. Martino ${ }^{1}$ (D) . S. Battaglia ${ }^{1} \cdot$ F. D'Alessandro ${ }^{1} \cdot$ M. Della Seta ${ }^{1} \cdot$ C. Esposito ${ }^{1}$. \\ G. Martini $^{2} \cdot$ F. Pallone ${ }^{1} \cdot$ F. Troiani ${ }^{1}$
}

Received: 30 July 2018 / Accepted: 26 February 2019 / Published online: 26 March 2019

(c) The Author(s) 2019

\begin{abstract}
Scenarios of earthquake-induced landslides are necessary for seismic microzonation (SM) studies since they must be integrated with the mapping of instability areas. The PARSIFAL (Probabilistic Approach to pRovide Scenarios of earthquake-Induced slope FAiLures) approach provides extensive analyses, over tens to thousands of square kilometers, and is designed as a fully comprehensive methodology to output expected scenarios which depend on seismic input and saturation conditions. This allows to attribute a rating, in terms of severity level, to the landslide-prone slope areas in view of future engineering studies and designs. PARSIFAL takes into account first-time rock- and earth-slides as well as re-activations of existing landslides performing slope stability analyses of different failure mechanisms. The results consist of mapping earthquake-induced landslide scenarios in terms of exceedance probability of critical threshold values of co-seismic displacements $\left(P\left[D \geq \operatorname{Dcla}(t), a_{y}\right]\right)$. PARSIFAL was applied in the framework of level 3 SM studies over the municipality area of Accumoli (Rieti, Italy), strongly struck by the 2016 seismic sequence of Central Apennines. The use of the PARSIFAL was tested for the first time to screen the Susceptibility Zones $\left(\mathrm{ZS}_{\mathrm{FR}}\right)$ from the Attention Zones $\left(\mathrm{ZA}_{\mathrm{FR}}\right)$ in the category of the unstable areas, according to the guidelines by Italian Civil Protection. The results obtained were in a GIS-based mapping representing the possibility for a landslide to be induced by an earthquake (with a return period of 475 years) in three different saturation scenarios (i.e. dry, average, full). Only $41 \%$ of the landslide-prone areas in the Municipality of Accumoli are existing events, while the remaining 59\% is characterized by first-time earth- or rock-slides. In dry conditions, unstable conditions or $\mathrm{P}\left[\mathrm{D} \geq \mathrm{Dcla}(\mathrm{t}), \mathrm{a}_{\mathrm{y}}\right]>0$ were for $54 \%$ of existing landslides, $17 \%$ of first-time rock-slides and $1 \%$ of first-time earthslides. In full saturation conditions, the findings are much more severe since unstable conditions or $\mathrm{P}\left[\mathrm{D} \geq \mathrm{Dcla}(\mathrm{t}), \mathrm{a}_{\mathrm{y}}\right]>0$ were found for $58 \%$ of the existing landslides and for more than $80 \%$ of first-time rock- and earth-slides. Moreover, comparison of the total area of the $\mathrm{ZA}_{\mathrm{FR}}$ versus $\mathrm{ZS}_{\mathrm{FR}}$, resulted in PARSIFAL screening reducing of $22 \%$ of the mapped $\mathrm{ZA}_{\mathrm{FR}}$.
\end{abstract}

Keywords Earthquake-induced landslides - Scenario mapping - Seismic microzonation · Italy

S. Martino

salvatore.martino@uniroma1.it

Extended author information available on the last page of the article 


\section{Introduction}

The reconstruction of landslide scenarios is a milestone for environmental planning in terms of both hazard mapping and strategic and engineering solutions to be adopted in urbanised areas. In particular, the awareness of the spatial distribution of earthquakeinduced landslides support the competent local authorities to plan intervention priorities aimed at managing the natural hazard on the basis of the available economic resources. The combined nature of the hazard related to earthquake-induced landslides implies that such processes should be analyzed taking into account both the proneness to failure (landslide susceptibility), and the probability of occurrence of the triggering event (seismic hazard).

However, the predisposing conditions to slope failures vary according to the environmental constraints, among which the water saturation of covers and deposits or the presence of pore water pressures related to groundwater flow, more commonly originated by impulsive events such as heavy rainfall. Nevertheless, for the purposes of spatial planning and its technical products (such as SM maps), the susceptibility mapping or the analysis of the spatial distribution of hazard related to the trigger action is not sufficient. Instead, it is necessary to resort to the reconstruction of scenario maps which have the dual purpose of: (1) providing a spatial distribution of effects to a certain probability of occurrence; and (2) make it possible to take into account their variability as a function of the predisposing environmental conditions, including soil saturation.

Since the late ' 80 s the prefiguration of earthquake-induced landslides scenarios, which means analyzing over large areas the proneness of slopes to fail under seismic loading, was strongly requested by scientific and technical communities for risk mitigation purposes. This goal was initially pursued by analyzing the maximum runout distances for the expected landslide occurrence (Keefer 1984; Rodriguez et al. 1999) on the basis of datasets obtained on a global scale. Afterwards, mapping solutions were proposed based on susceptibility or hazard analyses, whose development in the last few decades-significantly favored by the constant improvement over the years of computing facilities and GIS platforms-represent a well-established topic in the scientific and technical communities dealing with landslide risk reduction.

A first category of methods can be classified as physically-based approaches that are aimed at computing and mapping the safety factors and/or co-seismic displacements (Newmark 1965; Rathje and Bray 2000; Rathje and Antonakos 2011) under specific seismic loading (e.g., Prestininzi and Romeo 2000; Romeo 2000; Jibson et al. 2000; Jibson 2007; Hsieh and Lee 2011; Bozzano et al. 2013; Tsai et al. 2019). Such methods have the great advantage to explicitly consider the interaction slope-seismic waves, but also require a detailed knowledge of physical-mechanical properties of the slopes, which is not easy to achieve as the stability analyses should be extensively performed over wide areas. This issue can be relevant especially for first-time slope failures, while is less significant for landslide reactivation under seismic conditions if the geomechanical model of the slope is sufficiently constrained.

Other approaches strongly rely on indirect susceptibility or hazard assessments, such as those developed and widely used in the last decades. These are extensively described in the review papers by Reichenbach et al. (2018), encompassing a wide range of methods to assess at several scales both qualitatively and quantitatively the proneness of territories to almost each type of landslides. Most of the quantitative approaches are designed to perform susceptibility or hazard assessments on large scales; statistically-based models are commonly used. Due to the implications for earthquake-triggered landslide applications, 
it is worth highlighting one of the basic principles of this kind of methods: the assumption that past and present are the key to the future (Varnes and IAEG Commission on Landslides and other Mass-Movements, 1984), which means that these analyses are basically back analyses. Susceptibility models, especially if based on statistic approaches, are in fact trained and validated on already occurred landslides; this implies the availability of reliable landslide inventories. To turn susceptibility analyses in proper hazard analyses, the reference inventory should be referred to a specific triggering event with its temporal probability of occurrence as an earthquake (Harp et al. 2011). As a matter of fact, several earthquake-triggered landslide susceptibility analyses were performed by means of statistically-based methods exploiting event-based inventories (e.g., Xu et al. 2012a; García-Rodríguez and Malpica 2010; Kamp et al. 2008), which is by itself a way to consider, although implicitly, the role of the trigger. In other studies trigger-related factors (such as PGA, shake maps, Arias Intensity) referred to the triggering event have been explicitly considered as variables in the susceptibility function (e.g. Lee et al. 2008; Bai et al. 2012; Xu et al. 2012b; Lee et al. 2002; Tian et al. 2019). Such studies can be formally regarded as hazard analyses but being trained on event-based inventories and eventspecific triggers, their results are not easily generalizable to triggering events with different magnitudes.

Based on these premises, the PARSIFAL method (Esposito et al. 2016) has been developed trying to put together the benefits of both approaches in a comprehensive, multi-step methodology: a susceptibility assessment under static conditions (i.e., regardless the availability of an event-based inventory) is a screening tool to identify areas actually prone to landslides. The analysis can be carried out with the most reliable method depending on the data availability, i.e. quantitative statistically-based techniques or qualitative heuristic approaches, to provide the "background noise" in terms of landslide proneness of a given area, regardless the triggering factor. Subsequent physically-based analyses can be performed in the so-identified areas to assess landslide scenarios according to "customized" seismic inputs. This kind of integrated approach can be particularly suitable for sites featured by high levels of both seismic and landslide hazards, where no event-specific inventories are available and, thus, neither event-specific scenarios can be assessed by means of susceptibility approaches. Furthermore, the first step (slope analysis, explained further in more detail), which is actually the integration of landslide inventorying and susceptibility assessment for soil slopes and kinematic compatibility analyses for rock slopes, provides a basic and single input for pseudo-static and pseudo-dynamic analyses that can be performed under different seismic scenarios.

The PARSIFAL method considers different landslide typologies (new and existing in rock or soil) and different failure mechanisms. Some test sites of the method have been: (1) a coastal sector of Calabria in Southern Italy (Bozzano et al. 2013) as part of a POR project funded by the Calabria Region, (2) some municipalities of Central Italy (Esposito et al. 2016) as part of pilot studies promoted by the Lazio Region with high seismic hazard and, (3) in Spain (Martino et al. 2018), the Alcoy area in the Community of Valencia, historically hit by strong earthquakes and today intensely urbanized. The recent seismic events that struck the Central Apennines in 2016-2017 have launched an impressive reconstruction program that involves 15 municipalities in the province of Rieti, Lazio region. Thanks to the Ordinance of the Presidency of the Council of Ministers No. 24 of 12/05/2017 (OPCM 24/2017), technical support was provided for the design phase of the reconstruction by means of quantitative studies for SM which, following the guidelines issued in 2008 by the Italian Department of Civil Protection (DPC) (ICMS 2008), have provided the inventory of already unstable and potentially unstable slopes with the 
purpose of defining specific areas of attention for landslides $\left(\mathrm{ZA}_{\mathrm{FR}}\right)$. More specific landslides guidelines were recently published by the DPC (CTMS, 2017). According to these guidelines the areas of attention for slope failures $\left(\mathrm{ZA}_{\mathrm{FR}}\right)$ must be selected among the areas of susceptibility $\left(\mathrm{ZS}_{\mathrm{FR}}\right)$ that, compared to the former, constitute the subset of the areas for which: (1) the attitude to earthquake-induced failure can be evaluated quantitatively by means of simplified analytical approaches; (2) an area of invasion by debris accumulation or an area of expansion (AE) (for enlargement, advancement or retraction) should be associated.

In this study the procedure adopted in the Municipality of Accumoli is described. The SM studies followed ODPCM 24/2017) to obtain the perimeter of the $\mathrm{ZS}_{\mathrm{FR}}$ starting from the inventory of landslide areas $(\mathrm{ZF})$ and potentially unstable slopes (ZPF) which, together, define the zones of attention for landslide $\left(\mathrm{ZA}_{\mathrm{FR}}\right)$. This procedure, based on the construction of scenario maps referring to different types of failure mechanisms and to different conditions of saturation of deposits and covers, has been implemented starting from the previously experienced applications to SM studies and to the needs mapping standards of the DPC guidelines.

\section{Geological and geomorphological setting}

The geological and structural setting of the central Apennines is strongly influenced by the variable geodynamic context that characterized the Mediterranean area from the Triassic to the Neogene (Centamore et al. 2012; Cosentino et al. 2010).

The Accumoli area is characterised by a Meso-Cenozoic geological succession of limestones and marls with a thickness of about 8000 meters. The attitude of strata is strongly controlled by the folding and faulting responsible for the growth of the Apennine chain (Bigi et al. 2009) which evolved through a general northeastward migration towards the Adriatic foreland. This caused the formation of inner basin systems which hosted a thick turbiditic sedimentation during the Miocene (e.g. Laga Formation; Falcini et al. 2009, and references therein).

The present morpho-structural setting of Central Apennine is strongly driven by active extensional tectonics that characterizes this area since the Upper Pliocene. This extensional phase generated NW-SE-trending normal fault systems, which are responsible for the development of intermontane basins and include the main seismogenic sources of this sector of the Apennines (Tondi and Cello 2003; Galadini and Galli 2003; Boncio et al. 2004; Pizzi and Galadini 2009).

The Municipality of Accumoli is located in the piedmont zone of the Central Apennines, between the Sibillini Mountains to the west and the Laga Mountains to the east.

Most of the area is characterised by the outcropping of deposits ascribable to the flysch of the Laga Formation while the western portion is characterized by the outcropping of Meso-Cenozoic limestones and marls.

In general, the lithological variability of the study area accounts for different erosional behaviour along the main slopes (Fig. 1) and represents one of the main predisposing factors for intense mass wasting of slopes due to gravitational process.

Tectonics and climate influenced the long-term landscape evolution of this sector of the Apennines and the drainage network underwent important phases of planoaltimetric re-organization, mainly consisting in stream piracy and cyclic alternation of 


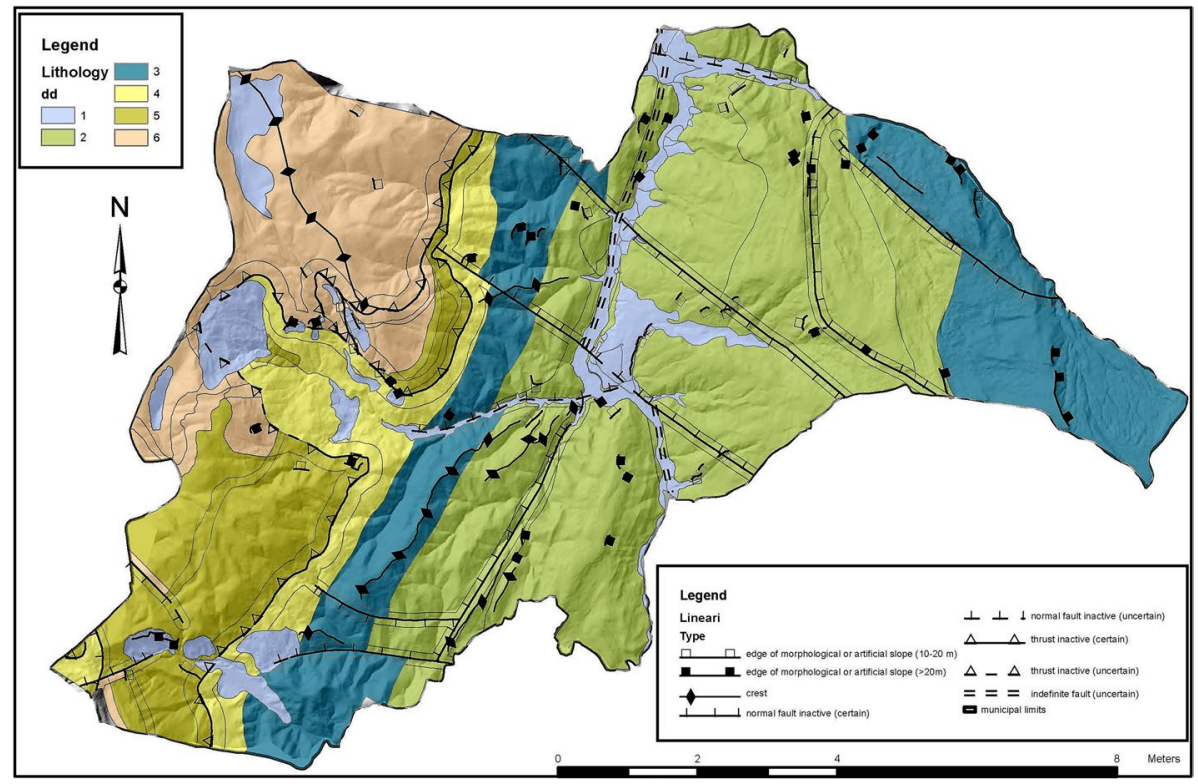

Fig. 1 Lithotechnical map of the Municipality of Accumoli with main morphostructural elements: (1) slope and alluvial deposits, (2) mostly arenaceous flysch, (3) mostly pelitic flysch, (4) marly clay, (5) marly limestone, (6) limestone

erosional and aggradational episodes, as already testified within adjacent river basins in central Apennines (Aringoli et al. 2014; Fubelli et al. 2014).

The geomorphological setting of the western portion of the area is characterized by deeply incised, mainly $\mathrm{V}$-shaped valleys and diffuse erosional landforms such as subvertical rocky cliff and ridges, which are particularly prone to landslides.

The remaining part of the area is divided by the Tronto River trunk-valley and presents a morphological asymmetry due to different characteristics of the outcropping bedrock (Fig. 1). The left valley-side, mostly carved into the arenaceous member of the Laga Formation, is featured by steep or sub-vertical slopes, ridges and V-shaped incised valley often interrupted, at various heights, by fluvial terraces and terrace-like morphologies of different origin. The opposite valley-flank, where the mostly pelitic member of the Laga Formation crops out, shows a gentle morphology and a quasicontinuous vegetation cover.

The Municipality of Accumoli is affected by several typologies of landslides mainly including roto-translational slides involving both rock masses as well as soils and rockfalls (sensu Hungr et al. 2014).

The mostly pelitic flysch of the Laga Formation is most affected by instability, since the presence of low shear strength pelitic interlayers, is the main predisposing factor to landslides activation. The strata attitude has great influence on the hillslope erosion, which is characterized by steeper anti-dip slopes with respect to dip slopes. These geological conditions represent a preparatory factor for planar sliding of rock blocks (Cacciuni et al. 1995). 


\section{Materials and methods}

\subsection{The PARSIFAL method}

The PARSIFAL method deals with the analysis of both re-activation of pre-existing landslides and the occurrence of first-time failures (Martino et al. 2018). First-time failures occur on slopes previously not affected by instabilities, while re-activation refer to already existing landslide that can be affected by further displacements. Both processes are triggered by either external or internal forces, such as seismic action and pore pressures increase related to intense rainfall events, respectively. Specifically, PARSIFAL analyzes re-activations of roto/translational slides and first-time failures that fall into two main categories: rock-slope failures and shallow earth-slides. To properly address the first stage (slope analysis) of the methodology, field surveys are of crucial importance to inventory already existing landslides and characterize rock masses and shallow deposits to assess their proneness to first-time failures.

The main output of PARSIFAL consists in a complete mapping of the probability of exceedance of earthquake-induced landslide displacement in respect to an assumed threshold, for different scenarios (i.e., return times of seismic hazard and saturation conditions).

PARSIFAL is a sequential procedure based on the following three main steps (Fig. 2):

Step 1 Slope Analysis (SA) - The territory is analyzed in terms of landslide susceptibility, regardless the dynamic input. As above mentioned, the methodology aims at analyzing the most common co-seismic landslides: re-activation of already existing roto/

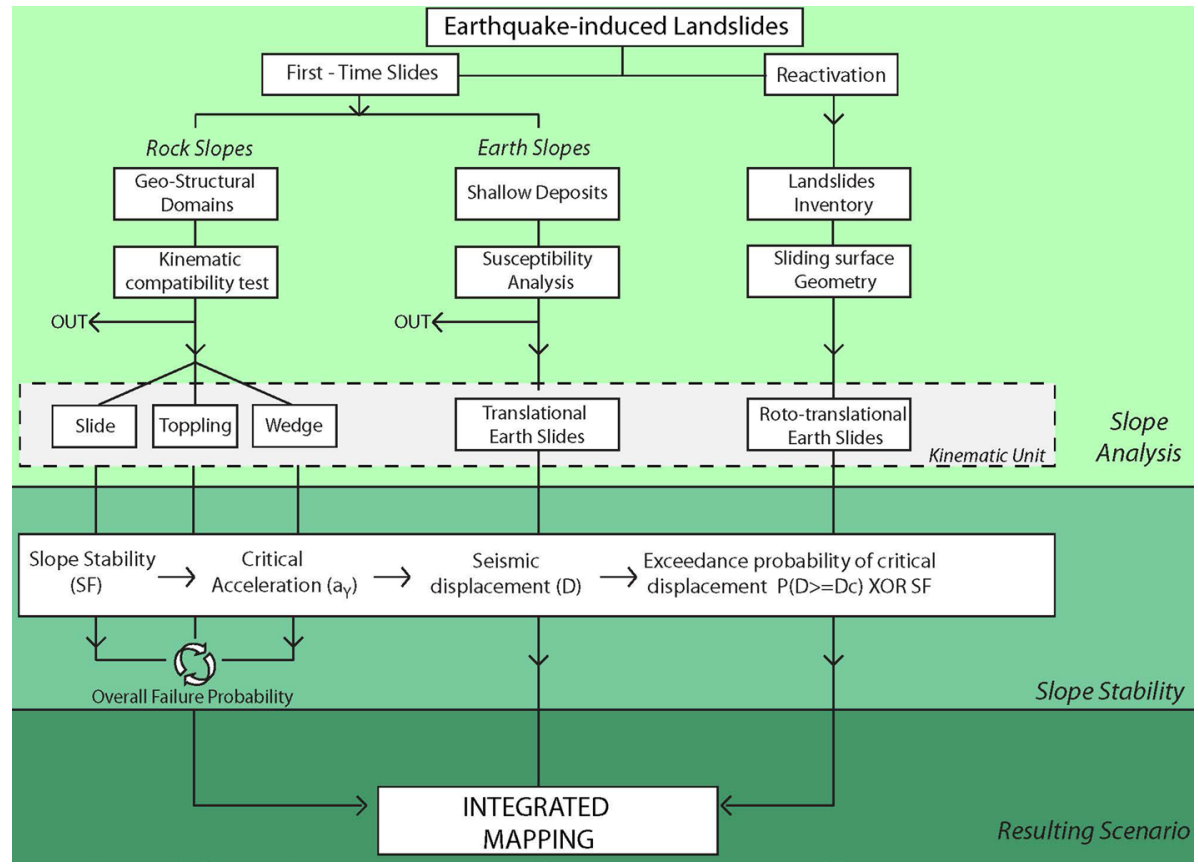

Fig. 2 Flow chart illustrating the multi-step PARSIFAL approach 
translational landslides, first-time rock-slope failures and newly generated shallow landslides of soil covers over the bedrock.

The susceptibility to re-activation is assessed by detecting and inventorying the already existing landslides which, in terms of GIS analysis, are mapped as polygons (Fig. 3). For first-time rock failures, the procedure is more articulated. In a first instance the territory is divided by identifying, on the basis of field surveys and related geo-structural and geomechanical measurements, zones that are homogeneous in terms of lithology and structural features (homogeneous geo-structural zones-HGZ). Each zone is then featured by a specific geometric pattern of discontinuity sets, that are in turn characterized in terms of geomechanical properties. The HGZs are then partitioned into a grid of square cells. A test of kinematic compatibility to planar/wedge sliding and toppling is performed by GIS routines on a cell-bycell basis by comparing dip and dip direction of each discontinuity sets (or trend and plunge of each line of intersection in the case of wedge mechanism) with slope and aspect of the corresponding cell, calculated starting from the available DEM (Digital Elevation Model) of the area. It is worth noting that each cell can be potentially compatible with more than one failure mechanism. With regards to first-time shallow landslides, i.e. the deposits potentially involved in shallow landslides, the proneness to failure is assessed after dividing each
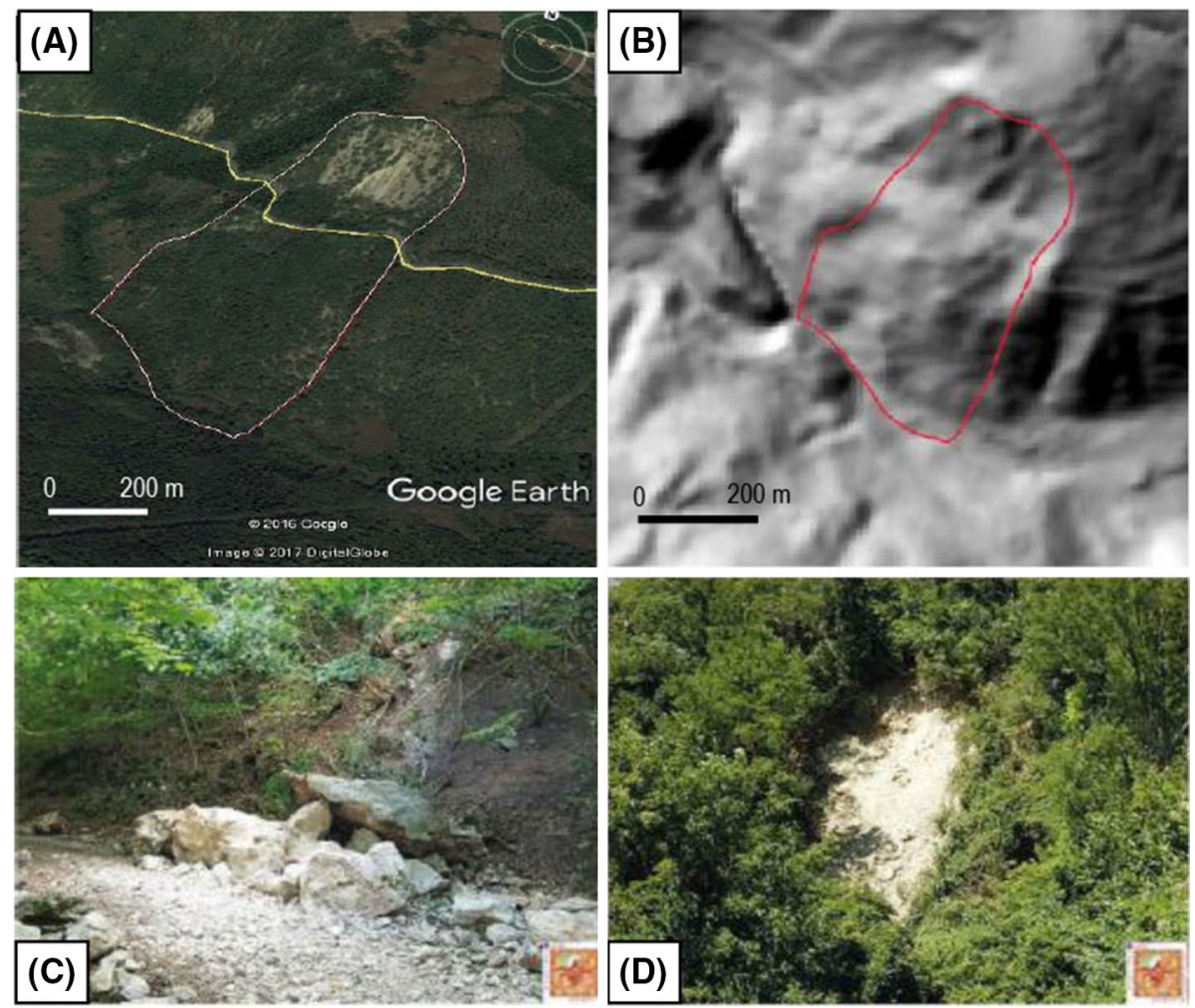

Fig. 3 Examples of landslide inventorying for PARSIFAL approach: a contour of landslide mass on satellite image (Google Earth), b contour of landslide mass on DEM, c picture of an inventoried earthquakeinduced rock fall from the on-line CEDIT catalogue, $\mathbf{d}$ picture of an inventoried earthquake-induced rock slide from the on-line CEDIT catalogue 
polygon representing a significant outcrop of soil cover into Unique Condition Units, i.e. subareas characterized by specific classes of slope exposure and lithology. The proneness of each UCU to landslides is then assessed by applying heuristic or quantitative susceptibility methods depending on data availability.

The territorial units resulting as susceptible to failure (grid cells in HGZs and UCU) or to co-seismic further displacements (polygons representing the inventoried existing landslides) are analyzed in the next step.

Step 2 Slope Stability (SS) - This step consists in the assessment of the actual potential of failure/re-activation under combined seismic and saturation loading of the areas resulted prone to failure in the previous phase. Specifically, this step aims at the computation of an exceedance probability of co-seismic displacements based on an assumed failure threshold and evaluated by the Newmark (1965) approach, i.e. considering a critical pseudostatic acceleration, $\mathrm{a}_{\mathrm{y}}$, as unelastic displacement threshold. The degree of mobility is expressed by the exceedance probability of a critical displacement $\left(\mathrm{P}\left[\mathrm{D} \geq \mathrm{Dcla}(\mathrm{t}), \mathrm{a}_{\mathrm{y}}\right]\right)$ responsible of the slope collapse, which can be assumed according to literature, as specified in the following. To calculate the degree of stability of landslides under seismic conditions, the input data considered are natural accelerometric records selected considering the seismological characteristics of the most severe seismogenic source among the ones that contribute to the seismic hazard of the site.

In case that the failure displacement threshold $\left(a_{y}\right)$ is not exceeded, a safety factor (SF) is computed as to provide a stability level of the slope. The SF is computed according to Limit Equilibrium Methods, selected on the basis of the landslide shape H/L (where $\mathrm{H}$ is the depth and $\mathrm{L}$ is the length of the landslide mass). In particular, according to Dewitte and Demoulin (2005): infinite slope method was adopted in case of $\mathrm{H} / \mathrm{L}<0.01$, the Janbu (1973) method was applied for slides characterized by $0.01 \leq \mathrm{H} / \mathrm{L} \leq 0.1$, i.e. with a mainly translational mechanism, the Bishop (1955) method was applied for a roto-translational mechanism (where $\mathrm{H} / \mathrm{L}>0.1$ ). Based on the previous reported definitions, three possible conditions can be expected by the computing: 1 ) for $\mathrm{a}_{\mathrm{y}}=0$ and $\mathrm{SF} \leq 1$ then $\left.\mathrm{P}\left[\mathrm{D} \geq \operatorname{Dcla}(\mathrm{t}), \mathrm{a}_{\mathrm{y}}\right]=1 ; 2\right)$ for $\mathrm{a}_{\mathrm{y}}>$ PGA and $\mathrm{SF}>1$ then $\left.\mathrm{P}\left[\mathrm{D} \geq \operatorname{Dcla}(\mathrm{t}), \mathrm{a}_{\mathrm{y}}\right]=0 ; 3\right)$ for $\mathrm{a}_{\mathrm{y}} \leq \mathrm{PGA}$ and $\mathrm{SF} \leq 1$ then $0<\mathrm{P}\left[\mathrm{D} \geq \operatorname{Dcla}(\mathrm{t}), \mathrm{a}_{\mathrm{y}}\right]<1$.

Step 3 Resulting scenario (RS) - This step aims at providing, for each considered scenario of combined seismic and saturation conditions, a synthetic and integrated GIS mapping of the slope stability results. The scenario map shows the different territorial units defined as elementary areas able to represent the slope stability results in terms of either failure exceedance probability or safety factor. To provide a unique value of $\mathrm{P}\left[\mathrm{D} \geq \mathrm{Dcla}(\mathrm{t}), \mathrm{a}_{\mathrm{y}}\right]$ into the same cell unit, the following criteria were assumed as reported in Martino et al. (2017): (1) for the same mechanism, the $P\left[D \geq D c l a(t), a_{y}\right]$ computed for different block volumes are solved in a unique value by performing a weight averaging; (2) combined probability is computed for each different mechanism (i.e., toppling, wedge sliding, planar sliding) using the probability values computed for each block volume; (3) in case that only SF values are computed for each block volume and landslide mechanism the lowest SF value is attributed to the cell unit, adopting a conservative solution. More in particular, in case of simultaneous presence of $n$-unstable blocks with $\mathrm{P}(\mathrm{D} \geq$ $\left.\mathrm{D}_{c}\right)>0$ for the same type of instability, the weighted exceedance probability, $P\left(D \geq D_{c}\right)_{w}$, is computed on the basis of the mobilized block volumes, according to the formula:

$$
P\left(D \geq D_{c}\right)_{w}=\frac{\sum_{i=1}^{n} P\left(D \geq D_{c}\right)_{i} \cdot V_{i}}{\sum_{i} V_{i}}
$$

where $P\left(D \geq D_{c}\right)_{i}$ is the probability of exceedance $\mathrm{P}\left[\mathrm{D} \geq \mathrm{Dcla}(\mathrm{t}), \mathrm{a}_{\mathrm{y}}\right]$ of the $i$ th rocky block size and $V_{i}$ its volume. 
In case more than one type of instability can occur, the overall failure probability is computed, according to the total probability theorem:

$$
P_{f}=1-\prod_{j}\left(1-P\left(D \geq D_{c}\right)_{j}\right)
$$

where $P\left(D \geq D_{c}\right)_{j}$ is the exceedance probability $\mathrm{P}\left[\mathrm{D} \geq \mathrm{Dcla}(\mathrm{t}), \mathrm{a}_{\mathrm{y}}\right]$ of the $j$ th type of instability (weighted, if any).

\subsection{From seismic inputs to exceedance probability}

In order to define a set of natural accelerometric records representative of the local expected ground-motion to be used in the evaluation of co-seismic displacements by Newmark (1965) approach, a constraint imposed by the general activity of level $3 \mathrm{SM}$ in the Central Italy area struck by 2016-17 seismic sequence (ODPCM 24/2017) has been adopted.

In detail, Luzi (2017) defined the seismic hazard level for the municipality area of Accumoli, according to the Italian national seismic map (Montaldo et al. 2007) and the Italian building code (NTC08-CS.LL.PP. 2008), for the selection of 7 natural accelerometric time-histories to be used as seismic input for local seismic response analysis by $1 \mathrm{D}$ and $2 \mathrm{D}$ engineering-geology numerical models.

The accelerometric records have been selected by the REXELite code (Iervolino et al. 2011) as to obtain time-histories spectrum-compatible with a target response spectrum evaluated for a Return Time of 475 years (i.e. a $10 \%$ exceedance probability within a reference time period of 50 years; obtained PGA $=0.26 \mathrm{~g}$ ), a Eurocode 8 site ground type "A" (hard rock/rock or Vs30 $\geq 800 \mathrm{~m} / \mathrm{s}$ ) and ground "flat" condition (i.e., slope angle $<15^{\circ}$ ). Further seismological parameters has been set in: (1) magnitude range 5.2-6.2 $\mathrm{M}_{\mathrm{W}}$ or $\mathrm{M}_{\mathrm{L}}$; (2) seismic source-site maximum distance $30 \mathrm{~km}$; focal mechanism "normal". The selection has been performed on the INGV ITalian ACcelerometric Archive (Luzi et al. 2008) increased with the records obtained by the temporary accelerometric network installed during the 2016-2017 Central Italy seismic sequence.

To increase the set of accelerograms to be used for the computation of the probability distributions of co-seismic Newmark's displacements, a further selection was performed (Martino et al. 2018) by querying additional accelerometric databases like ESM-Engineering Strong-Motion database release 1.0 (Luzi et al. 2016) or Japanese NIED strongmotion seismograph networks (website: http://www.kyoshin.bosai.go.jp/). The previously mentioned selection criteria are extended to: (1) a Eurocode 8 site ground type "A" and "B", which are the most representative for the thickness as well as for the geotechnical and geophysical parameters of the deposits outcropping in the study area; (2) "freefield" or "ground" recording-sites; iii) Focal mechanism "normal" or "normal-oblique", i.e. in the rake interval $-20^{\circ} /-70^{\circ}$ (normal left-lateral oblique); $-70^{\circ} /-110^{\circ}$ (normal); $-110^{\circ} / 160^{\circ}$ (normal right-lateral oblique); iv) hypocentral depth $\mathrm{h} \leq 30 \mathrm{~km}$. Additional constraints involved the selected time-histories in term of: PGA which must fulfill the condition $0.67 \leq \mathrm{PGA} \leq 1.5$ of local seismic hazard; Arias intensities (in base-10 logarithm values) lying inside the $95 \%$ confidence interval of that computed from the selected records; shape similarity of response spectra compared to the target one, evaluated for a Return Time of 475 years, for different period intervals. Finally, the resulting time-histories are scaled to the local seismic hazard PGA, namely $0.26 \mathrm{~g}$.

Considering both the selection criteria, a set of 25 natural accelerometric records is collected (Fig. 4a) and used for the evaluation of Newmark (1965) co-seismic displacements. 
Assuming a critical displacement threshold of $10 \mathrm{~cm}$ for earth-slides and $5 \mathrm{~cm}$ for rock-slides, according to Romeo (2000), the probability of exceedance $P\left[D \geq D c l a(t), a_{y}\right]$ for each landslide or instability area can be evaluated

In detail, for every local ground instability, the pseudo-static critical acceleration $\left(a_{y}\right)$ evaluated at different saturation conditions allow the identification of accelerations which can induce a co-seismic displacement. By a double-integration of time-history accelerations overcoming the ay acceleration, a cumulative co-seismic displacement is calculated (Fig. 4b). In this way, a set of 25 maximum cumulative co-seismic displacement values is obtained: Fig. 4c shows the distribution of relative frequencies of obtained maximum displacements, in terms of base-10 logarithm, compared as example with the $\mathrm{x}$-axis position of the critical displacement threshold for rock-slides.

It is therefore assumed that the co-seismic displacements obtained by applying the Newmark's method to the selected time-histories are distributed according to a normal distribution characterized by an average $(\mu)$ :

$$
\mu=\frac{\sum_{i=1}^{N t h} \log 10\left(S p_{i}\right)}{N}
$$

(A)
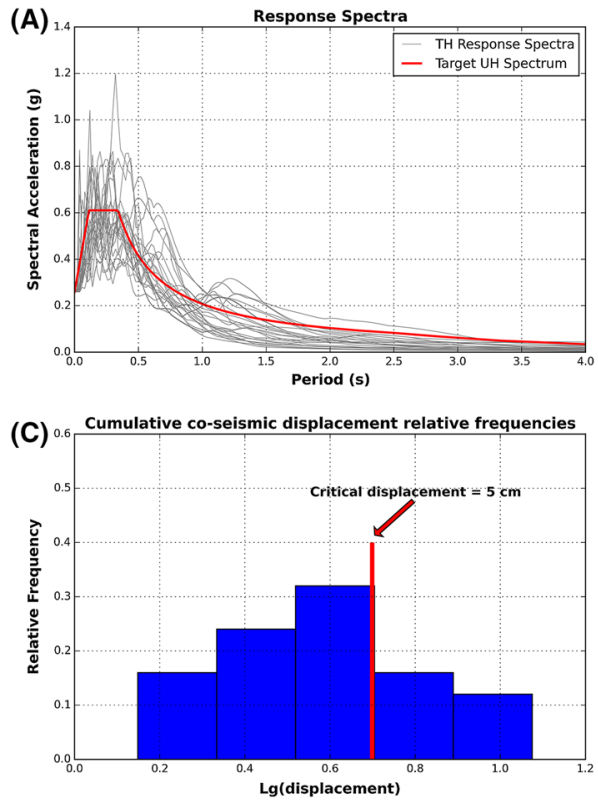

(B)

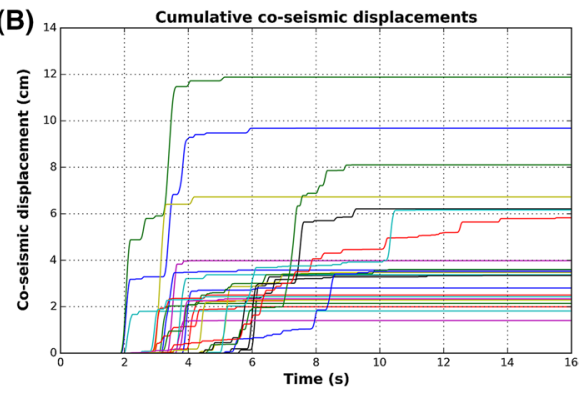

(D)

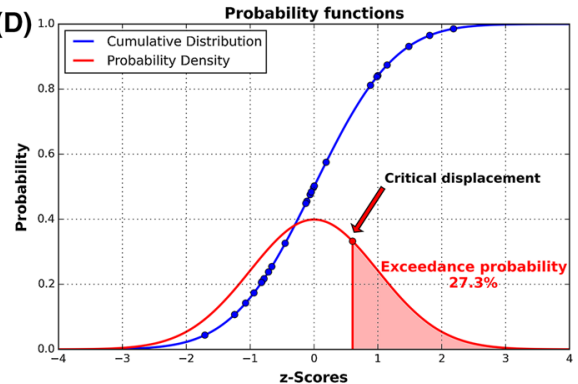

Fig. 4 Procedure and data used for the assessment of exceedance probability in an example instability (herein rock-slide): a response spectra of selected input time-histories (thin grey lines) compared with the target response spectrum (bold red line), b cumulative co-seismic displacements evaluated by Newmark (1965) by an example $\mathrm{a}_{\mathrm{y}}$ pseudo-static critical acceleration, $\mathbf{c}$ distribution of relative frequencies of maximum displacements, in terms of base-10 logarithm, compared with the $\mathrm{x}$-axis position of the critical displacement threshold ( $5 \mathrm{~cm}$ for rock-slide), $\mathbf{d}$ probability functions from maximum cumulative displacements distribution: in blue the Cumulative Distribution Function with overlapped the probability of each maximum co-seismic displacement, in red the Probability Density Function of obtained standard normal distribution compared with the probability of the critical displacement threshold expressed in standard unit (z-Score) and (light red area) the resulting exceedance probability 
and a standard deviation $(\sigma)$ :

$$
\sigma=\sqrt{\frac{\sum_{\mathrm{i}=1}^{\mathrm{Nth}}\left[\log 10\left(\mathrm{Sp}_{\mathrm{i}}\right)-\mu\right]^{2}}{\mathrm{~N}(\mathrm{~N}-1)}}
$$

where $N$ is the number of selected time-histories and $\log 10\left(S p_{i}\right)$ is the base-10 logarithm of i-th maximum cumulative co-seismic displacement.

The probability of occurrence of a critical displacement calculated by means of the standard normal distribution (i.e. with mean $\mu=0$ and standard deviation $\sigma=1$ ) is given by the equation:

$$
\operatorname{Prob}(x)=1-\left(\int_{-\infty}^{S p C r} \frac{1}{\sqrt{2 \pi}} e^{-\frac{1}{2} z^{2}}\right)
$$

where $\mathrm{x}$ is the base-10 logarithm of critical displacement, $\log 10(\mathrm{SpCr})$, and $\mathrm{z}$ is the critical displacement expressed in standard unit (z-Score):

$$
z=\frac{[(\log 10(\mathrm{SpCr})-\mu)]}{\sigma}
$$

Therefore, for a given local ground instability and pseudo-static critical acceleration $\left(\mathrm{a}_{\mathrm{y}}\right)$ evaluated at different saturation conditions, the exceedance probability of a critical displacement (Fig. 4d) is obtained from the equation:

$$
\mathrm{P}\left[\mathrm{D} \geq \operatorname{Dc} \mid \mathrm{a}(\mathrm{t}), \mathrm{a}_{\mathrm{y}}\right]=1-\operatorname{Prob}(x)
$$

\section{Results}

For both first-time failures and re-activations the Newmark (1965) co-seismic displacements were computed by using the selected time histories and by considering the previously derived $\mathrm{a}_{\mathrm{y}}$ values for each typical rock block and earth-slide mass at different saturation conditions. Following this approach, the landslide mass is considered like a rigid block sliding on an inclined plane (in case of planar sliding) or on a curved surface (in case of roto-translational slides) as well as on an intersection line (in case of wedge sliding). For the rock blocks, only toppling mechanism was also accounted for and driving forces are considered to produce an overturning moment. Each block has $\mathrm{a}_{\mathrm{y}}$ values which represents the threshold seismic acceleration required for triggering the landslide failure. Thematic maps were obtained through GIS by synthetically reporting the slope stability conditions under dynamic action as well as the probability of exceedance of the critical displacement referred to scenarios of different saturation conditions.

Each territorial unit corresponding to a landslide mass or to a landslide prone area was classified with a color scale corresponding to the computed probability of exceedance (Fig. 5).

In case of null probability (i.e. no statistic of Newmark displacement computed) the resulting safety factor was attributed to the corresponding territorial unit. As it resulted by the PARSIFAL application to Accumoli area, up to $2 \%$ of the entire municipal territory correspond to already unstable or landslide-prone areas. Within this area, 59\% is 
Fig. 5 Legend to the PAR-

SIFAL output: the colour scales correspond to different $\mathrm{P}\left[\mathrm{D} \geq \operatorname{Dcla}(\mathrm{t}), \mathrm{a}_{\mathrm{y}}\right]$ values for soil and rock landslides respectively

\section{LEGEND}

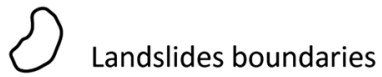

SOIL ROCK
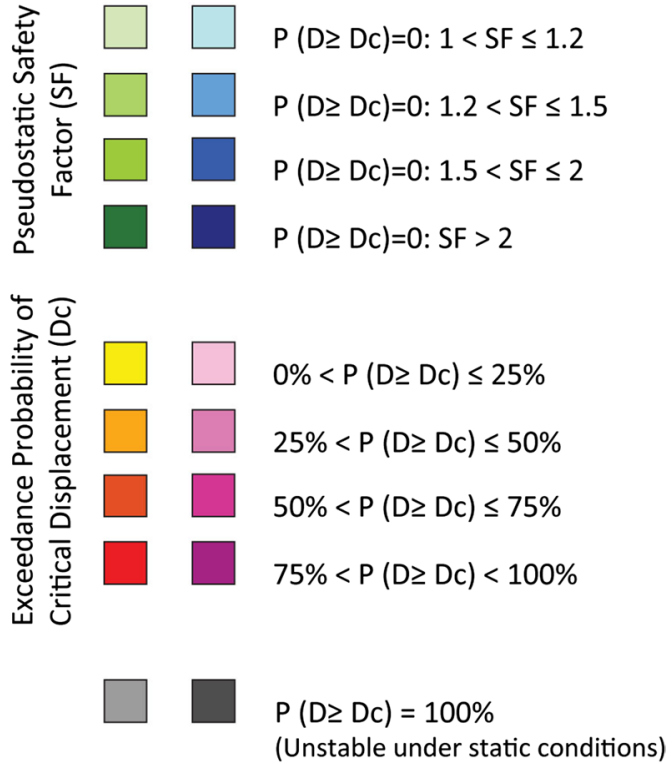

represented by first-time landslides (33\% rock mass failures and $26 \%$ shallow debris covers) and $41 \%$ correspond to re-activation of already existing landslides.

In the dry condition RS (Fig. 6) for the first-time landslides in rock mass, 17\% are unstable and in no case has a probability of exceedance been obtained $\left(0<\mathrm{P}\left[\mathrm{D} \geq \mathrm{Dcla}(\mathrm{t}), \mathrm{a}_{\mathrm{y}}\right]<1\right)$. The first- time landslides in shallow debris cover are stable for the $99 \%$ while for the $1 \%$ a $\left(0<\mathrm{P}\left[\mathrm{D} \geq \mathrm{Dcla}(\mathrm{t}), \mathrm{a}_{\mathrm{y}}\right]<1\right)$ was computed. Among the already existing landslides, the $46 \%$ have $\mathrm{a}\left(0<\mathrm{P}\left[\mathrm{D} \geq \operatorname{Dcla}(\mathrm{t}), \mathrm{a}_{\mathrm{y}}\right]<1\right)$ and the $8 \%$ are unstable $\left(\mathrm{P}\left[\mathrm{D} \geq \operatorname{Dcla}(\mathrm{t}), \mathrm{a}_{\mathrm{y}}\right]=1\right)$.

In the middle saturation RS (Fig. 7) for the first-time landslides in rock mass, $83 \%$ are unstable and in no case has a probability of exceedance been obtained $\left(0<\mathrm{P}\left[\mathrm{D} \geq \mathrm{Dcla}(\mathrm{t}), \mathrm{a}_{\mathrm{y}}\right]<1\right)$. Among the first-time landslides, in shallows debris cover it was obtained a probability of exceedance $\left(0<\mathrm{P}\left[\mathrm{D} \geq \mathrm{Dcla}(\mathrm{t}), \mathrm{a}_{\mathrm{y}}\right]<1\right)$ for the $41 \%$. For already existing landslides, $29 \%$ are unstable $\left(\mathrm{P}\left[\mathrm{D} \geq \operatorname{Dcla}(\mathrm{t}), \mathrm{a}_{\mathrm{y}}\right]=1\right)$ and it was obtained a probability of exceedance $\left(0<\mathrm{P}\left[\mathrm{D} \geq \operatorname{Dcla}(\mathrm{t}), \mathrm{a}_{\mathrm{y}}\right]<1\right)$ for the $42 \%$.

In the full saturation scenario (Fig. 8), due to the severity of the assumed condition, for all the shallow debris cover susceptible for first-time landslides was obtained a probability of exceedance $\left(0<\mathrm{P}\left[\mathrm{D} \geq\right.\right.$ Dcla $\left.\left.(\mathrm{t}), \mathrm{a}_{\mathrm{y}}\right]<1\right)$ while the results for first-time landslides in rock mass do not change respect to the middle saturation scenario. Among the already existing landslides the $58 \%$ became unstable $\left(\mathrm{P}\left[\mathrm{D} \geq \operatorname{Dcla}(\mathrm{t}), \mathrm{a}_{\mathrm{y}}\right]=1\right)$ and for the $17 \%$ probability of exceedance $\left(0<\mathrm{P}\left[\mathrm{D} \geq \operatorname{Dcla}(\mathrm{t}), \mathrm{a}_{\mathrm{y}}\right]<1\right)$ have been computed. 


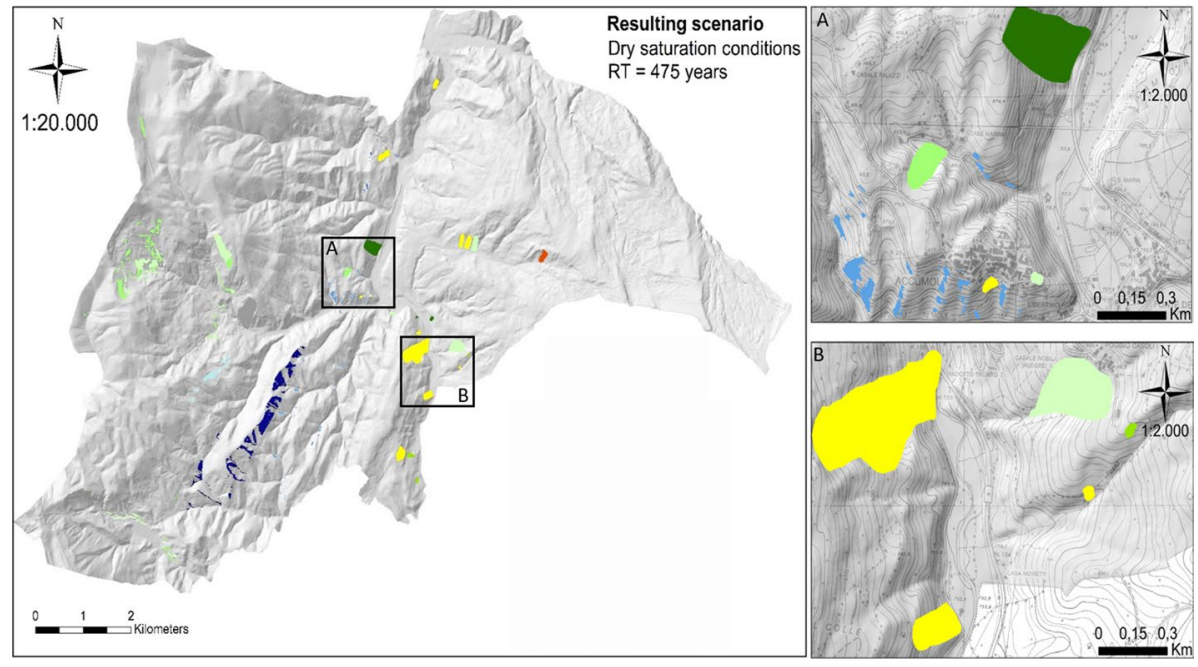

Fig. 6 Resulting scenario from PARSIFAL referred to dry conditions (see Fig. 6 for legend), the zoomed excerpts are details of the mapping
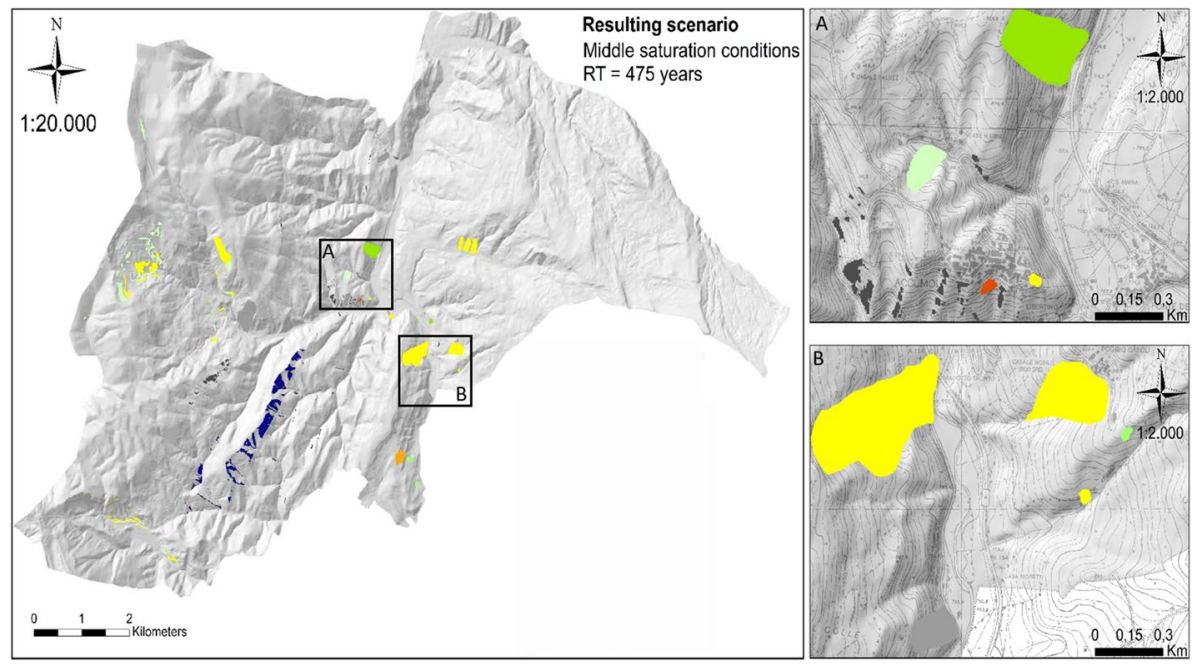

Fig. 7 Resulting scenario from PARSIFAL referred to middle-saturation conditions (see Fig. 6 for legend), the zoomed excerpts are details of the mapping

\section{Discussion}

Following the DPC guidelines (ICMS 2008; CTMS, 2017) referred to landslides, the Zones of Attention $\left(\mathrm{ZA}_{\mathrm{FR}}\right)$ are areas in which the available data indicate the presence of conditions predisposing the slope failures but are not sufficient to define if instability can actually occur in case of earthquake; nevertheless, through the consultation of inventories like the on-line CEDIT catalogue (Martino et al. 2014; Martino 2017-www.ceri. 


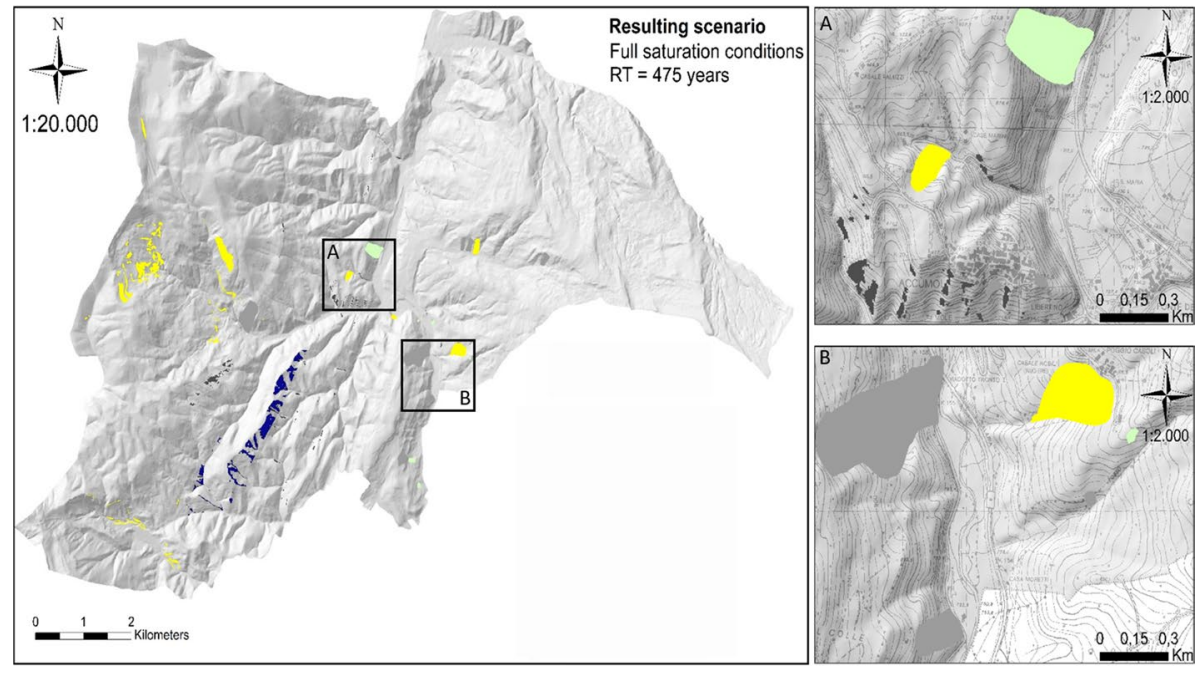

Fig. 8 Resulting scenario from PARSIFAL referred to full saturation conditions (see Fig. 6 for legend), the zoomed excerpts are details of the mapping

uniroma1.it/index.php/web-gis/cedit), it is possible to document the occurrence of landslide events during historical earthquakes.

Susceptibility Zones $\left(\mathrm{ZS}_{\mathrm{FR}}\right)$ are areas to which it is possible to attribute a non-null earthquake-induced hazard through simplified methods of analysis.

Respect Zones $\left(\mathrm{ZR}_{\mathrm{FR}}\right)$ are areas in which it is possible to quantify the caused danger as well as the involvement area due to an earthquake-induced landslide through quantitative approaches. The identification of the $\mathrm{ZA}_{\mathrm{FR}}$ allows to perform, in a subsequent level of analysis, a "screening" operation that output from the mapped areas (including the already unstable and the potentially unstable ones) those that can be activated in case of earthquake by the use of simplified methods (pseudo-static). The landslide areas that should be unstable in case of earthquake occurrence will constitute the $\mathrm{ZS}_{\mathrm{FR}}$ dataset and its related mapping. Only more specific and in-depth studies will lead to verify the specific stability conditions of the landslide slopes leading to obtain the $\mathrm{ZR}_{\mathrm{FR}}$ map starting from the $\mathrm{ZS}_{\mathrm{FR}}$ one. The application of the PARSIFAL methodology has made it possible to define scenario maps referring to different conditions of debris and cover saturation. In particular, the methodology aimed at deducting the $\mathrm{ZS}_{\mathrm{FR}}$ map starting from the scenario maps initially obtained; they were taken into account all the results obtained in the three considered scenarios reconstructed by PARSIFAL, therefore as the saturation conditions range from zero to the admissible maximum, the final susceptibility was attributed through a weighting of the probabilities of exceedance resulting from all the reconstructed scenarios.

If in two of the three considered saturation scenarios the probability of exceedance was non-zero, i.e. a statistic for the earthquake-induced displacements was calculated, the $\mathrm{ZA}_{\mathrm{FR}}$ was converted into a $\mathrm{ZS}_{\mathrm{FR}}$ and deemed to be subject to further in-depth studies for evaluating its admissibility as $\mathrm{ZR}_{\mathrm{FR}}$, i.e. for the purposes of planning engineering designs to be provided.

Expansion areas (AE) with a buffer of 10 meters around the landslide, following the DPC recommendations (ICMS 2008; CTMS 2017), have been defined only for already 
existing landslides, since in case of first-time debris slides the distribution of activity (sensu Varnes 1978) cannot be attributed.

In case of rock slides and toppling, the AE were defined according to the shadow cone approach (as suggested by ICMS 2008), involving the maximum distances that could be reached by the detached blocks (runout distance). The shadow cones were defined through the Conefall 1.0 software (http://conefall.software.informer.com/1.0/), which allows to obtain an estimate approximate area of invasion of an unstable block from the local DEM.

Through the performed application PARSIFAL proved to be a valid methodological approach to make the screening between $\mathrm{ZA}_{\mathrm{FR}}$ and $\mathrm{ZS}_{\mathrm{FR}}$ (Fig. 9), as required by the DPC guidelines with the advantages:

(1) to return the set of ZF (already existing landslides) and ZPF (first generation landslides) that can be integrated with the landslide bodies already registered by the IFFI (Inventario dei Fenomeni Franosi in Italia—http://www.isprambiente.gov.it/it/progetti/suolo -e-territorio-1/iffi-inventario-dei-fenomeni-franosi-in-italia) and PAI (Piani di Assetto Idrogeologico - http://www.regione.lazio.it/prl_ambiente) catalogues, assigning to each identified unstable area a level of hazard, expressed as the exceedance probability with respect to a trigger threshold;

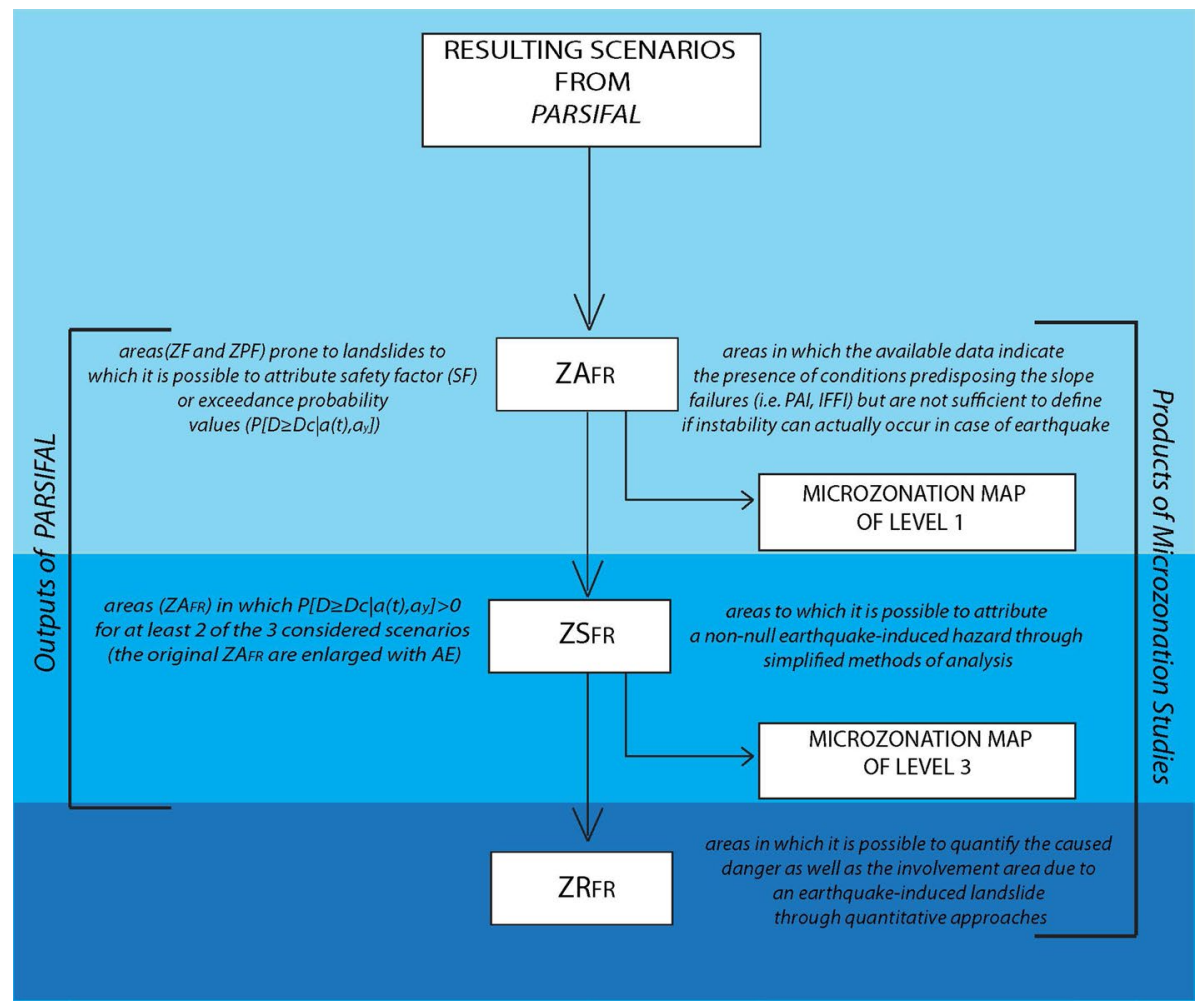

Fig. 9 Flow chart illustrating the link between the outputs from PARSIFAL and the products of level 3 SM (following ICMS 2008) 
(2) to allow a screening between $\mathrm{ZA}_{\mathrm{FR}}$ and $\mathrm{ZS}_{\mathrm{FR}}$ based on a comparison among different analyses of scenario that take into account the variability of environmental predisposing conditions (specifically the saturation of land and cover);

(3) to be flexible with respect to specific needs related to the SM activities envisaged by ODPCM 24/2017, including in particular: i) the preservation of areas already bound by the PAI among the $\mathrm{ZS}_{\mathrm{FR}}$ (regardless of scenario solutions); ii) the pre-selection of ZPF areas by means of dimensional threshold spatial filters, commensurate with the size of the building and therefore of the vulnerable elements; iii) the epistemic error due to the variability/uncertainness of mechanical parameters values that could be taken into account through parametric analyses.

More in detail, for the Municipality of Accumoli, based on the results obtained by the screening performed through PARSIFAL, the $Z_{\mathrm{FR}}$ result as sub-dataset of the $\mathrm{ZA}_{\mathrm{FR}}$ (Fig. 10). By comparing the total area of the $\mathrm{ZA}_{\mathrm{FR}}$ with the total area of the $\mathrm{ZS}_{\mathrm{FR}}$, it results that the PARSIFAL screening led to a reduction of $22 \%$ of the mapped $\mathrm{ZA}_{\mathrm{FR}}$.

A limitation to the current application of PARSIFAL consists in not being able to take into account the anthropic slopes coinciding with the cuts of the road trenches both for lack of resolution of the DEM used, and for the necessity to verify the suitability of the slope-to-road system to different types of failure mechanisms: (1) shallow sliding of debris covers existing upstream of the cut; (2) sliding of the road plan; (3) sliding of the slope immediately downstream of the roadway.

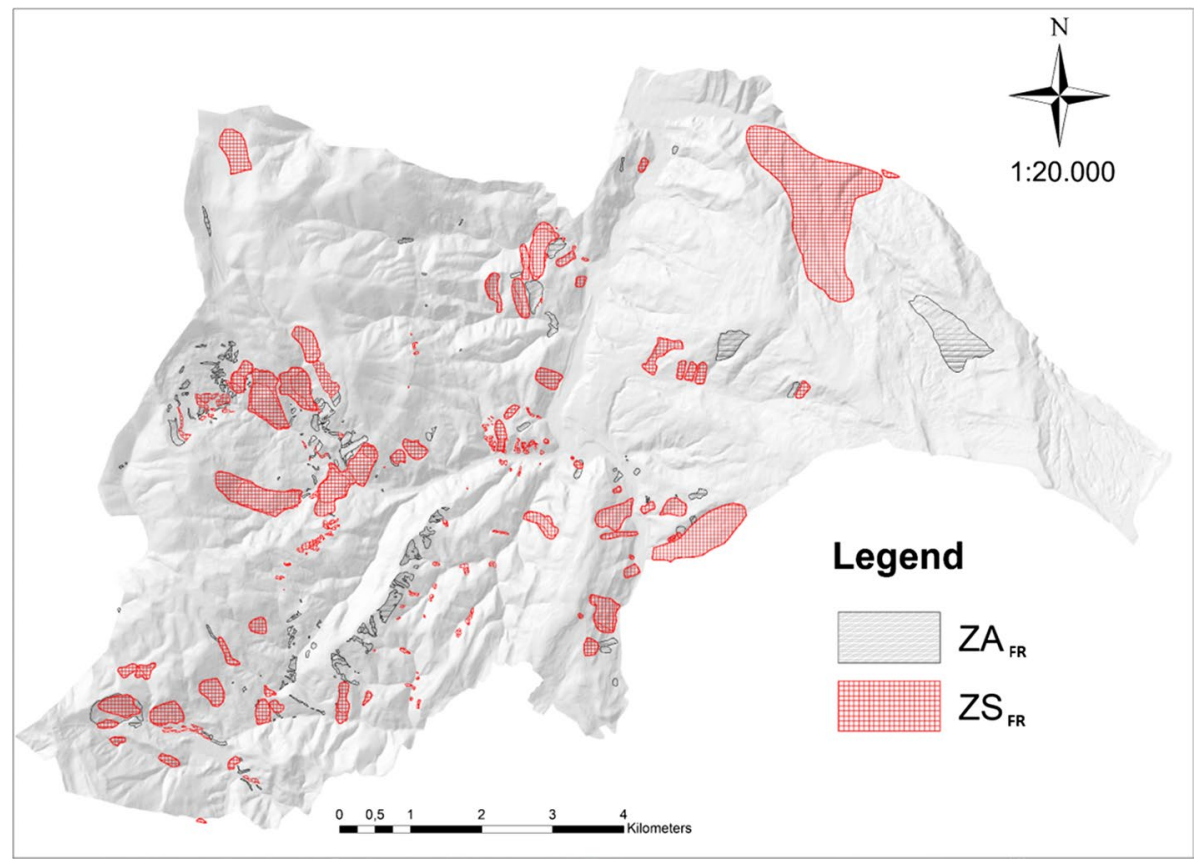

Fig. 10 Maps of $\mathrm{ZA}_{\mathrm{FR}}$ and $\mathrm{ZS}_{\mathrm{FR}}$. The $\mathrm{ZS}_{\mathrm{FR}}$ map was derived after the PARSIFAL screening adding the $\mathrm{AE}$ to the screened $\mathrm{ZA}_{\mathrm{FR}}$ 


\section{Conclusions}

Quantitative studies of SM provided by ODPCM 24/2017 have made it possible to test the PARSIFAL approach for the screening of landslide areas $\left(\mathrm{ZA}_{\mathrm{FR}}\right)$, including the already existing landslides and potentially unstable areas, for the purpose of selecting zones susceptible to landslide $\left(\mathrm{ZS}_{\mathrm{FR}}\right)$, according to the provisions of the DPC guidelines for SM studies.

To this aim, PARSIFAL has been used to compare different scenarios of earthquakeinduced landslides in the Municipality of Accumoli, thus being able to weigh the predisposition to the mobilization of already unstable or prone to failure slopes (the latter both in soil and in rock) in relation to predisposing environmental conditions, in particular the saturation from zero to the maximum admissible.

Therefore, all the $\mathrm{ZA}_{\mathrm{FR}}$ were considered susceptible to landslide $\left(\mathrm{ZS}_{\mathrm{FR}}\right)$ if in two of the three scenarios reconstructed by the saturation conditions it was possible to calculate a non-zero probability of exceedance with respect to the assumed threshold of co-seismic displacement considered for the failure. The $\mathrm{ZS}_{\mathrm{FR}}$ also included all the areas already subject to hydrogeological restrictions by the current technical legislation (PAI).

In perspective, PARSIFAL can be considered a valid screening tool between $\mathrm{ZA}_{\mathrm{FR}}$ and $\mathrm{ZS}_{\mathrm{FR}}$ with the advantage of being able to be applied to extended territorial scales and with the possibility to be implemented in the future for taking into account anthropic cuts, i.e. in correspondence with the road trenches where, based on the evidence gathered during the seismic crisis of 2016-2017 in the Central Apennines, the highest percentage of landslide rock falls occurred.

Aknowledgements The Authors wish to thank the Municipality of Accumoli for the logistic support to the field activities; G. Di Martino, L. Falconi, C. Missori and C. Puglisi for collecting part of the field data; C. Di Marzio and D. Marchetti for providing the public technical data and reports on seismic microzonation studies that they performed at Accumoli. S. Martino coordinated the research activities; M. Della Seta and F. Troiani performed the geomorphological surveys; F. D'Alessandro performed the engineering-geological surveys and the slope stability analyses; S. Battaglia, C. Esposito, G. Martini and F. Pallone managed the PARSIFAL procedure, computation and mapping. The study was carried out in the framework of the Ordinance of the Presidency of the Council of Ministers No. 24 of 12/05/2017 (ODPCM 24/2017) managed by the Centro per la Microzonazione Sismica e le sue Applicazioni of the Italian National Research Council (CNR). The authors recall with esteem and affection the late colleague Roberto Romeo with whom this study began.

Open Access This article is distributed under the terms of the Creative Commons Attribution 4.0 International License (http://creativecommons.org/licenses/by/4.0/), which permits unrestricted use, distribution, and reproduction in any medium, provided you give appropriate credit to the original author(s) and the source, provide a link to the Creative Commons license, and indicate if changes were made.

\section{References}

Aringoli D, Cavitolo P, Farabollini P, Galindo-Zaldivar J, Gentili B, Giano SI, Lòpez-Garrido AC, Materazzi M, Nibbi L, Pedrera A, Pambianchi G, Ruano P, Ruiz-Constàn A, Sanz de Galdeano C, Savelli D, Tondi E, Troiani F (2014) Morphotectonic characterization of the quaternary intermontane basins in the Umbria-Marche Apenniness (Italy). Rendiconti Lincei 25(2):11-128

Bai S, Wang J, Zhang Z, Cheng C (2012) Combined landslide susceptibility mapping after Wenchuan earthquake at the Zhouqu segment in the Bailongjiang Basin, China. CATENA 99:18-25

Bigi S, Milli S, Corrado S, Casero P, Aldega L, Botti F, Moscatelli M, Stanzione O, Falcini F, Marini M, Cannata D (2009) Stratigraphy, structural setting and burial history of the Messinian Laga basin in the context of Apennine foreland basin system. J Mediterr Earth Sci 1:61-84 
Bishop AW (1955) The use of the slip circle in the stability analysis of slopes. Géotechnique 5:7-17

Boncio P, Lavecchia G, Pace B (2004) Defining a model of 3D seismogenic sources for seismic hazard assessment applications: the case of central Apenniness (Italy). J Seismol 8:407-425

Bozzano F, Esposito C, Martini G, Martino S, Prestininzi A, Rinaldis D, Romeo RW, Scarascia Mugnozza G (2013) Earthquake-reactivated landslide scenarios in Southern Italy based on spectral-matching input analysis. Bull Earthq Eng 11:1927-1948

Cacciuni A, Centamore E, Di Stefano R, Dramis F (1995) Evoluzione morfotettonica della conca di Amatrice. Studi Geologici Camerti 1995(2):95-100

Centamore E, Fumanti F, Nisio S (2012) The Central-Northern Apennines geological evolution from Triassic to Neogene time. Boll Soc Geol It 1(2002):181-197

Cosentino D, Cipollari P, Marsili P, Scrocca D (2010) Geology of the central Apennines: a regional review. J Virtual Explorer. https://doi.org/10.3809/jvirtex.2010.00223

CS.LL.PP. (2008). DM 14 gennaio, Norme tecniche per le costruzioni. Gazzetta Ufficiale della Repubblica Italiana 29

CTMS - Commissione tecnica per la microzonazione sismica (2017). Linee guida per la gestione del territorio in aree interessate da instabilità di versante sismoindotte (FR). https://www.centromicrozona zionesismica.it/it/download/category/13-linee-guida-per-la-gestione-del-territorio-in-aree-interessat e-da-instabilita-di-versante-cosismiche

Dewitte O, Demoulin A (2005) Morphometry and kinematics of landslides inferred from precise DTMs in West Belgium. Nat Hazards Earth Syst Sci 5:259-265

Esposito C, Martino S, Pallone F, Martini G, Romeo R (2016) A methodology for a comprehensive assessment of earthquake-induced landslide hazard, with an application to pilot sites in Central Italy. In: Landslides and engineered slopes. Experience, theory and practice, Taylor and Francis Inc. 2: 869-877

Falcini F, Marini M, Milli S, Moscatelli M (2009) An inverse problem to infer paleoflow conditions from turbidites. J Geophys Res 114:C10019

Fubelli G, Della Seta M, Amato G (2014) Drainage system adjustment in response to the opening of the Rieti intermontane basin (Central Italy): geostatistical reconstruction of the PaleoFarfa River alluvial plain. Rendiconti Lincei 25(S2):167-176

Galadini F, Galli P (2003) Paleoseismology of silent faults in the central Apennines (Italy): the Mt. Vettore and Laga Mts. faults. Ann Geofis 46:815-836

García-Rodríguez MJ, Malpica JA (2010) Assessment of earthquake-triggered landslide susceptibility in El Salvador based on an Artificial Neural Network model. Nat Hazards Earth Syst Sci 10:1307-1315

Harp EL, Keefer DK, Sato HP, Yagi H (2011) Landslide inventories: the essential part of seismic landslide hazard analyses. Eng Geol 122:9-21

Hsieh SU, Lee CT (2011) Empirical estimation of the Newmark displacement from the Arias intensity and critical acceleration. Eng Geol 122:34-42

Hungr O, Leroueil S, Picarelli L (2014) The Varnes classification of landslide types, an update. Landslides 11(2):167-194

ICMS (2008) Gruppo di lavoro MS, Indirizzi e criteri per la microzonazione sismica, Conferenza delle Regioni e delle Province autonome-Dipartimento della protezione civile, Roma, 2008, 3 vol. e Dvd

Iervolino I, Galasso C, Paolucci R, Pacor F (2011) Engineering ground motion record selection in the ITalian ACcelerometric Archive. Bull Earthq Eng 9(6):1761-1778

Janbu N (1973) Slope stability computations Embankment Dam Engineering Casagrande Memorial Volume. Wiley, New York, pp 47-86

Jibson RW (2007) Regression models for estimating coseismic landslide displacement. Eng Geol 91:209-218

Jibson RW, Harp EL, Michael JA (2000) A method for producing digital probabilistic seismic landslide hazard maps. Eng Geol 58:271-289

Kamp U, Growley BJ, Khattak GA, Owen LA (2008) GIS-based landslide susceptibility mapping for the 2005 Kashmir earthquake region. Geomorphology 101:631-642

Keefer DK (1984) Landslides caused by earthquakes. Geol Soc Am Bull 95(4):406

Lee S, Choi J, Min K (2002) Landslide susceptibility analysis and verification using the Bayesian probability model. Environ Geol 43(1-2):120-131

Lee CT, Huang CC, Lee JF, Pan KL, Lin ML, Dong JJ (2008) Statistical approach to earthquake-induced landslide susceptibility. Eng Geol 100:43-58

Luzi L (2017) Rapporto tecnico sulla selezione di un insieme di 7 accelerogrammi compatibili con lo spettro di normativa (NTC08), da utilizzare come input per le simulazioni numeriche della microzonazione sismica di terzo livello (Ordinanza n. 24 del 12 maggio 2017)

Luzi L, Hailemikael S, Bindi D, Pacor F, Mele F, Sabetta F (2008) ITACA (ITalian ACcelerometric Archive): a web portal for the dissemination of Italian Strong-motion Data. Seismol Res Lett 79(5):716-722 
Luzi L, Puglia R, Russo E, ORFEUS WG5 (2016) Engineering strong motion database, version 1.0. Istituto Nazionale di Geofisica e Vulcanologia, Observatories \& Research Facilities for European Seismology

Martino S (2017) Earthquake-induced landslides in Italy: from the distribution of effects to the hazard mapping. Ital J Eng Geol Environ 1(2017):53-67

Martino S, Prestininzi A, Romeo RW (2014) Earthquake-induced ground failures in Italy from a reviewed database. Nat Hazards Earth Syst Sci 14:799-814

Martino S, Battaglia S, Delgado J, Esposito C, Martini G, Missori C (2018) Probabilistic approach to provide scenarios of earthquake-induced slope failures (PARSIFAL) applied to the Alcoy Basin (South Spain). Geosciences 8(57):1-20

Montaldo V, Meletti C, Martinelli F, Stucchi M, Locati M (2007) On-line seismic hazard data for the new italian building code. J Earthq Eng 11(S1):119-132

Newmark NM (1965) Effects of earthquakes on dams and embankments. Geotechnique 15(2):139-159

ODPCM (2017) Ordinanza n. 24 del 12 maggio 2017, Assegnazione dei finanziamenti per gli studi di microzonazione sismica di III livello ai Comuni interessati dagli eventi sismici verificatisi a far data dal 24 agosto 2016 e proroga di termini di cui all'ordinanza n. 13 del 9 gennaio 2017. https://sisma 2016.gov.it/wp-content/uploads/2017/05/Ordinanza-24-del-12-maggio-2017.pdf

Pizzi A, Galadini F (2009) Pre-existing cross-structures and active fault segmentation in the northern-central Apennines (Italy). Tectonophysics 476(1-2):304-319

Prestininzi A, Romeo R (2000) Earthquake-induced ground failures in Italy. Eng Geol 58:387-397

Rathje EM, Antonakos G (2011) A unified model for predicting earthquake-induced sliding displacements of rigid and flexible slopes. Eng Geol 122:51-60

Rathje EM, Bray JD (2000) Nonlinear coupled seismic sliding analysis of earth structures. J Geotech Geoenviron Eng ASCE 126(11):1002-1014

Reichenbach P, Rossi M, Malamud BD, Mihir M, Guzzetti F (2018) A review of statistically-based landslide susceptibility models. Earth Sci Rev 180:60-91

Rodriguez CE, Bommer JJ, Chandler RJ (1999) Earthquake induced landslides: 1980-1997. Soil Dynam Earthq Eng 18:325-346

Romeo RW (2000) Seismically induced landslide displacements: a predictive model. Eng Geol 58:337-351

Tian Y, Xu C, Hong H, Zhou Q, Wang D (2019) Mapping earthquake-triggered landslide susceptibility by use of artificial neural network (ANN) models: an example of the 2013 Minxian (China) Mw 5.9 event. Geomat Nat Hazards Risk 10:1-25

Tondi E, Cello G (2003) Spatio-temporal evolution of the central Apenniness fault system (Italy). J Geodyn 36:113-128

Tsai HY, Tsai CC, Chang WC (2019) Slope unit based approach for assessing regional seismic landslide displacement for deep and shallow failure. Eng Geol 248:124-139

Varnes DJ (1978) Slope movements types and processes. In: Schuster RL, Krizek RJ (ed) Landslides-analysis and control. 12-33, National Academy of Sciences and Transportation Research Board, Special report 176

Varnes DJ (1984) IAEG Commission on landslide and other mass movement on slopes (1984) Landslide hazard zonation: A review of principles and practice. The UNESCO Press, Paris, p 63

Xu C, Dai F, Xu X, Lee YH (2012a) GIS-based support vector machine modeling of earthquake-triggered landslide susceptibility in the Jianjiang River watershed, China. Geomorphology 145-146:70-80

Xu C, Xu X, Dai F, Saraf AK (2012b) Comparison of different models for susceptibility mapping of earthquake triggered landslides related with the 2008 Wenchuan earthquake in China. Comput Geosci $46: 317-329$

Publisher's Note Springer Nature remains neutral with regard to jurisdictional claims in published maps and institutional affiliations.

\section{Affiliations}

\section{S. Martino ${ }^{1}$ (1) - S. Battaglia ${ }^{1}$. F. D'Alessandro ${ }^{1} \cdot$ M. Della Seta ${ }^{1}$. C. Esposito ${ }^{1}$. G. Martini ${ }^{2} \cdot$ F. Pallone ${ }^{1} \cdot$ F. Troiani ${ }^{1}$}

1 Dipartimento di Scienze della Terra e Centro di Ricerca per i Rischi Geologici (CERI), Università di Roma Sapienza, P.za A. Moro 5, 00185 Rome, Italy

2 Agenzia Nazionale per le Nuove Tecnologie, l'Energia e lo Sviluppo Economico Sostenibile (ENEA), Via Enrico Fermi, 45, 00044 Frascati, Rome, Italy 